\title{
A Framework of U.S. Contemporary Police Training: Select Types of Basic Training and Purpose of Field, Inservice, and Specialized Training
}

\author{
Richard H. Martin \\ Correspondence: Richard H. Martin, Criminal Justice \& Homeland Security, Mercer University, USA.
}

Received: May 10, 2020

Accepted: May 28, 2020

Online Published: June 10, 2020

doi:10.11114/jets.v8i7.4892

URL: https://doi.org/10.11114/jets.v8i7.4892

\begin{abstract}
The article illustrates an overview of the various types of police training in the United States. It includes types of mandatory minimum annual training within the states, the purpose, importance, and benefits of various types of police training. The types of training include basic training (e.g., sponsored academy basic training and preservice self-pay basic training), field training officer (FTO), roll-call training (e.g., recent incidents, new updates), inservice training (e.g., legal updates, firearms, community policing, mental health issues, wellness), and specialized training (e.g., SWAT training, traffic enforcement, hostage and barricaded subjects, promotions, dealing with issues in the community). Relevancy of training curriculum and validation of selection criteria are| also addressed.
\end{abstract}

Keywords: police basic training, preservice basic training, preemployment basic training, inservice training, field training

\section{Introduction}

All law enforcement officers (LEOs) within municipalities and counties, including members of state police agencies in the United States are required to participate in basic training, the initial step for police certification or licensing. Basic training takes place either in the traditional academy or in a preservice basic training program, usually offered at a community college. Both are commonly labeled basic training. The main difference is in a preservice setting, the candidate self-pays for training costs and is not yet employed by an agency, whereas a candidate in a traditional academy has been selected by an agency to participate in basic training. Selection methods for police officers address whether a police candidate is capable of being successful in training, especially basic training by having cutoff scores on aptitude tests. It should also measure whether the candidate will have the attributes necessary for a career in policing (Martin, 2020).

An extension of basic training is field training with a field training officer, designed primarily to prepare an officer for solo patrol or to weed out the recruit. Roll-call training or briefing is designed to inform a new shift about certain incidents or community issues. Inservice training generally involves review and enhancing skills and information. Inservice training builds knowledge beyond fundamental information learned in basic training, and it builds confidence and proficiency of skills. It is arguable that well-trained officers have a more professional approach to the job. A professional attitude is a reflection on the department, and helps build the support of the community (Martin, 2019). According to a required accreditation standard of the Commission for Accreditation of Law Enforcement Agencies (CALEA, 2006), training "fosters cooperation and unity of purpose" (p.33-1).

The purpose of the article is to present a summary of the types of police training in the United States. It is a review of the literature on police training the purposes of police training.

\section{Literature Review}

\subsection{National Law Enforcement Research Agenda}

Research conducted by the International Association of Chiefs of Police (IACP) in 2007 indicated an interest in researching several areas of policing. There were two areas found to have especially strong interest, selection and training. The research findings were published in the first National Law Enforcement Research Agenda (NLERA), with selection and training listed as main concerns (IACP, 2008). It is important to note that almost all topics listed in the NLERA required some aspect of training. The NLERA study results can be used to determine LEO success by 
combining the procedural aspects of selection with training, including basic training, field training, mentoring, and inservice training programs. All of the items in the survey addressed characteristics promoting LEO success (Martin, 2014).

\subsection{Training Relevancy}

Relevancy of training can be determined through validation with selection criteria. The validity of a training program is established by comparing selection criteria against the learning outcomes of training. Results of the selection, training, and probationary evaluations of new personnel are typically compartmentalized and kept separate (Martin, Gwynne, \& Hamilton, 2013). How valid are the processes used for recruit selection and training? According to Hunter (1994), the criteria for selection and training curricula are seldom linked to evaluating selection component validity. Criteria and methods used for selection and training need to be validated in a coordinated selection evaluation process. Data on components of recruit preparation, selection, training, and how they complement each other should be evaluated and compared against each component (Hunter, 1994). Comparing information can determine what improvements are needed. Information sharing can improve training programs for police officers and determine relevancy of training programs.

\subsection{Common Perception}

The common perception of police work is enforcement of traffic and criminal laws; however, most police work involves provision of service and maintaining order, not making arrests. Providing service and maintaining order are dominant police activities, although situations arriving out of these two functions may result in an arrest. It is common in the literature that 15-20 percent of police work is enforcement of laws, and about 80 percent of LEO functions have a social service and order maintenance purpose (Walker \& Katz, 2019). Police administrators should ask the question of whether current police training is actually relevant, that is, does the training curriculum covers the most important aspects of policing? The curricula of the basic training academies should cover situations that involve recognizing and dealing with mental illness, domestic disturbances, race relations, discretion, ethical decision making, and human relations, just to name a few (Walker \& Katz, 2019). Basic training curriculum should include contemporary content. For instance, hostage and barricaded subject situations are not usually part of most basic training curriculum, but is left up to inservice training or special units as in larger cities. Hostage situations and barricaded subjects are frequent incidents in Atlanta, but Atlanta started training for these situations less than 10 years ago (Benton \& Martin, 2012). Another training concern besides relevancy is a lack of full-time instructors held accountable for training outcomes. In addition, since training impacts performance and subsequent evaluations, in order to be considered successful, training programs should be either relevant or revised.

Managers and supervisors in a department are generally used as part-time instructors rather than having full-time instructors. College professors may have research credibility, but can they relate their research to police practices on the streets (Thibault, Lynch, \& McBride, 2004)? Instruction that relates theory to practice can convey more accurately what happens on the streets is very important in training. Relating research to the streets portrays more realistically and may be life saving for the recruits. Another concern is having proper training facilities, media, and technology that facilitate learning outcomes. For example, role-playing enriches learning during training. The use of DVDs to illustrate interactive scenarios on shooting decisions boosts both basic and inservice training (Thibault et al., 2004). A pedagogical style of straight lecturing during training is the easiest way to lose the attention of trainees. Adult learners prefer the andragogical style with audience interaction, it is proven to be the best way to maintain their attention.

Training should provide skills for officers to advance their careers and build self-confidence while increasing their responsibilities to work effectively in various conditions (Miller, More, \& Braswell, 2017). Review of police activity should be conducted frequently and training curricula updated as necessary to keep it current. Training and the technology used in training should relate to the actual work environment (street realism) as thoroughly as possible. Attendance at training seminars should be mandatory for trainees, but care must be taken so that the training is not perceived as a disciplinary action. Inservice training on legal updates and procedures, new department policies, and overall KSA's should be a continuing activity (Thibault et al., 2004). Ongoing inservice training is a solid defense for civil lawsuits and legal claims (Ross, 2000). Civil courts use the standard of deliberate indifference during failure-to-train lawsuits (Martin, 2014). Kappeler's research at Eastern Kentucky University found that failure to supervise is as bad as failure to train, and results in many secondary claim civil lawsuits (Ross, 2000).

Alpert and Dunham argued in 1997 that training is an essential tool required to enhance and sustain capable police performance (Miller, et al., 2017). Knowledge and skills are developed through study and training. It can be argued that officers who understand their role and have acquired good job skills will also have higher morale. Well-trained officers are self-assured, perform better and have professional attitudes. Annual police supervisory performance evaluations include a review of prior training as part of the evaluation. Training and continuing education are some of the elements 
required of a profession. The other elements of a profession include authority, specialization, self-governing discretion, a defined body of information, self-regulating standards, a code of ethics, and an internalized aspect of societal service (Miller, et al., 2017). There are three broad types of police training, basic, field, and inservice (Gaines, Worrall, Southerland, \& Angell, 2003; Peak, \& Glensor, 2012).

\subsection{Mandatory Basic Training}

All states have statutes requiring officers to be state certified, with a few states requiring licensing. Both fall under the direction of what is commonly known as Police Officer Standards and Training (POST) certification. Some states allow a grace period of up to 12 months to police on the streets before having to attend a basic training academy. About 45 percent of police academies in the U.S. are aligned with colleges and universities, but mostly community colleges. About 22 percent of all training academies are aligned with large agencies, for example Chicago and New York City. State police run seven percent of the academies, and eight percent of all academies are run by multi agency confederations made up of small agencies within a geographical area. About 53 percent of the academies follow a pedagogical militaristic high stress related style of instruction and about 47 percent follow an andragogical model. The rationale for the latter is adults like to interact during instruction. Required training hours vary from 586 hours for smaller agencies in populations areas under 10,000 to 1,783 hours for agencies in population areas of a half million and more. Totals include both academy and field training hours (Oliver, 2020, pp. 137-138). Field training programs are an extension of basic training and are extremely stressful because of the constant evaluation of the probationary officer (Oliver, 2020, p.139). One of its purposes serves as a weeding out process for most agencies. It is a good practice to determine whether an officer's deficiencies are remedial. They may have the qualities to become good officers after additional training to prevent potentially good officers from being terminated during probation.

Traditionally, basic training has been offered to recruits in an agency or state academy. In the past 30 years, basic training in community colleges as preservice or pre-employment basic training has increased. Preservice training is where applicants attend a community college program and pay for their own training. This trend has replaced academy basic training for many smaller agencies and has gained popularity around the country (Martin, 2014; More, et al., 2017). By 2014, there were 32 states with pre-employment certification legislation for police basic training (Martin, 2016). The state finalizes the certification when the candidate secures a job. However, most community colleges prefer to treat basic training as an add-on endeavor while in school or as a summer internship.

Preservice basic training (AKA pre-employment) is cost effective as well as a hiring pipeline for police agencies. Potential recruits pay their basic training certification costs in this method. There is no guarantee the student will be hired by an agency after completing the basic training with degree requirements; however, students will learn how well their chances are of being hired by a police agency while in the precertification program. Shepherd and Austin (as cited in Miller et al., 2017) view this preservice training method of self-payment is a passageway to a true police profession. Ideally, the learning outcomes of basic training curriculum and the academic curriculum should be integrated. For example, the Police Education Delivery System (PEDS) developed at Elgin Community College (Martin, 2014) in the early 1990s was one of the first truly integrated preservice learning outcome programs where students received a two-year degree and completed the Illinois basic training curriculum for certification. The reputation of an integrated preservice program (as opposed to the add-on method) has a direct bearing on the acceptance of applicants into police agencies (Martin, 2014). Mandatory basic training in all states have a range of 10 to 48 weeks, with annual requirements of an additional number of hours of inservice training.

After completing basic training and qualifying for certification, a recruit moves to field training (probationary status) which is an extension of basic training under the tutelage of a field-training officer (FTO). During probation and later with inservice training, job proficiency is improved and self-confidence begins to increase. It can be argued that confident and skilled officers tend to work harder, and are better employees with a more professional attitude. A professional attitude is a more visually professional officer that reflects on the department. It is hoped that professional policing gains community respect and support. According to a standard of the Commission for Accreditation of Law Enforcement Agencies (CALEA), training "fosters cooperation and unity of purpose" (2006, p. 33-1).

There are three training standards established by CALEA; two are required for accreditation and one is optional for agencies. The two mandatory training standards for agency accreditation: are Standard 33.4 that addresses recruit training and Standard 33.5 that addresses inservice training. The optional standard is (33-6) which addresses specialized inservice training (CALEA, 2006, pp. 33-5-33-9). However, if the agency has specialized training, it must have a written standard.

The benefits of inservice and specialized training are familiarity of operational information and building of self-confidence, according to Gaines and Worrall (2012). Additionally, officers are known to work harder and are more capable (2012). Gaines and Worrall argued that knowledgeable officers tend to have a more professional demeanor and 
more likely to be respected by the community (2012). The right selection criteria can determine whether police applicants can be trained successfully.

In addition to better performance skills, training provides police with more confidence, and they seem to develop higher levels of morale. Relevant training programs develop qualified officers and as such, the training is regarded as successful. Prior training, especially inservice training, is a consideration of supervisors during the annual officer performance evaluations (Gaines \& Worrall, 2012; More \& Miller, 2007).

According to More and Miller (2007), "Training is the one essential tool that is required to create, enhance, and maintain effective police performance" (p. 505). When LEOs understand their job and have the skills to perform, they are more self-assured and have a more professional attitude and better performance, as such they usually have increased levels of morale. Thus, since demands of the job are frequently changing, continuous education and training is imperative. Training programs must be relevant to be considered successful. The most important factor in determining reliability and credibility of police training programs is the ability to determine basic suitability factors of those participating in the training programs. The training process should allow participants to gain new knowledge and achieve personal goals, in addition to meeting organizational needs (Martin \& Gwynne, 2010, p. 5).

Pre-employment basic training for certification (also known as precertification basic training) was traditionally provided by an agency after selection of a new recruit. However, pre-employment or preservice training is exceeding academy basic training. Preservice certification usually takes place at a community college. Individuals pay their own costs for basic training before obtaining a police position. Preservice training has increased in the past 20 years (More \& Miller, 2007, p. 507). Ideally, community colleges should integrate learning outcomes of criminal justice academic and vocational curricula of the associate degree courses with police basic training curriculum learning outcomes. Police candidates simultaneously receive an associate degree and a police certificate in a true integrated basic training and academic curriculum so students earn an associate degree and basic training requirements at the time of graduation (Martin, 2014). When examining both academic and basic training curricula, it can be seen that 90 percent of basic training curriculum is the same content as criminal justice curriculum (Martin, 2014). Keep in mind that some states require recruits to secure a job before being approved for certification (Martin, 2014).

Preservice programs are very cost-effective for hiring agencies and is a radical change in public policy. According to Shepherd and Austin, this system of self-payment for preservice training is a pathway to a true profession for policing (as cited in More \& Miller, 2007). The reputation of the preservice training program and the applicant's qualification determine acceptance by an agency (p. 508). Mandatory basic training is required by all states. They also have a required number of hours of inservice police training. Most states certify officers and only a few license officers. Decertification is more difficult than not renewing an annual license. Decertification generally results from an officer arrest, but not renewing a license may be the result of an officer not completing prescribed annual criteria in addition to arrests.

One result of good training is individual morale increases. For example, when personnel understand their jobs and have the skills to perform required tasks, they have better confidence which leads to increased morale (Martin \& Gwynne, 2010). Acquiring skills and knowledge of the job is not only gained in formal training, field training, and on-the job training, but also in education. Self-assurance produces better performance and just may provide officers with a more professional attitude. In order to have these benefits, training programs must be relevant. Relevancy is determined by individual and agency needs, and validity of the program curriculum. Without these, it is difficult for training programs to be successful. In annual and semi-annual reviews of performance, prior training is one of the considerations of supervisors' evaluation. There is consensus among agencies that good training is imperative.

The two methods of candidate's involvement in basic training is either after candidates are selected during the agency recruiting process, or through pre-employment basic training. Aspiring police applicants that choose preservice basic training pay their own expenses during basic training with the hope of securing a position in policing when finished. Preservice is mostly offered through community colleges. Preservice training has gained in popularity around the country in the past 25 years (More \& Miller, 2007, p. 507). A number of community colleges award an associate degree at the same time they award the basic training certificates. When the learning outcomes of academic courses are integrated with the learning outcomes of basic training curriculum, students have a unique opportunity for employment, i.e., an associate degree with police certification. When basic training learning outcomes are integrated into the academic and vocational curriculum, students finish with a two-year degree and precertification completed (Martin, 2014). Shepherd and Austin view this method of self-payment for basic training as a gateway to law enforcement being a true profession (More \& Miller, 2007). Acceptance into a police agency from a school with integrated training is in part, based on the reputation of the preservice training as well as the qualification and characteristics of the applicant (p. 508).

Police training includes three broad areas: (1) basic training in preparation for police work, (2) inservice training 
dedicated to the review and updating of skills and knowledge (includes roll-call training), and (3) specialized or career development training (Gaines, Worrall, Southerland, \& Angell, 2003, p. 374). Inservice training develops competence. Competence provides confidence and knowledge, which in turn, produces officers that work harder and more effectively. Training "fosters teamwork and unison of purpose (CALEA, 2006, p. 33-1). Well-trained officers tend to be more professional, which contributes to more respect from the community. The selection process should determine whether applicants have the ability to be trained, sometimes more assessment than just an attitude test.

Alpert and Dunham stated about 20 years ago, "training is the one essential tool that is required to create, enhance, and maintain effective police performance" (as cited in More \& Miller, 2007, p. 505). Police officers with the knowledge, traits, and skills to perform policing proficiently through training generally have higher levels of morale. Their demeanor is professional, and they are more confident. Training must be relevant to develop competent officers; it also ensures successful training programs. Supervisory performance evaluations generally consider prior training in their evaluations.

\subsection{Predicting Successful Training}

Candidate selection is the first step in determining whether police officers will be successful in basic training. It begins with an application followed by an aptitude test. The more comprehensive the written application, the more it will eliminate those not motivated for the position (Martin \& Gwynne, 2010). Some important points to consider when selecting methods of measurement during selection include the following: (1) type and purpose of instruments used for testing, (2) depth of inquiry in instruments used, (3) measurement of discretionary decision- making and the ability to make street-level decisions, (4) success rate of recruits in the academy, (5) problems encountered during field training and the probationary period, and (6) remedial deficiencies versus deficiencies subject to termination (Martin et al., 2013). The latter three points are critical in helping determine success in basic training.

\subsection{Mandatory Fitness Requirement}

Standards for physical ability should not be overlooked when determining the selection criteria. It can predict success in basic training since a physical ability test is required by most state basic training academies. Some states require a certain physical ability standard be met for entry into the academy and before certification. Some only require candidates take the test before the academy to measure their fitness and what they need to correct for graduation. The POWER test developed by the Cooper Center for Aerobics Research in Dallas is used by many departments to measure aerobic capacity and upper body strength with the testing scaled for age and sex (Martin, 2000). Cooper measurements include the mile and a half run, sit-ups and push-ups in a minute, and sit and reach. All are adjusted by sex and age. Some academies include a standing jump (Weber State, n.d.). Weber also includes measurements when entering academy and exiting academy to show improvement. According to Grossi (2007), other tests can range from the timed running, push-ups, sit-ups, standing-broad-jump measurement, to the more job-specific test, such as dragging an object simulating a person, trigger-pull (hand strength), vaulting a vertical wall three to four foot high, and climbing through a window test.

Other examples of physical tests are those required for FBI Jobs. Testing and requirements include situps: maximum number of continuous situps in one minute; sprint: timed 300-meter sprint; pushups: maximum number of continuous pushups (untimed); run: timed 1.5-Mile Run; and pullups: maximum number of continuous pullups for candidates in Tactical Recruitment Program (fbijobs.gov, n.d.).

Grossi questioned whether there were fitness standards after being on the job? Should inservice officers be required to pass physical fitness standards, either annually or biannually? Some agencies do have fitness standards, but most do not. Larger departments may require annual medical examinations, complete with blood tests, and EKGs, in addition to annual physical fitness evaluations. Having facilities and providing duty time for working out seems to be rare based on a survey of police chiefs in 2018 (Moore, Martin, \& Lin, 2019).

A clearance from a medical provider may be required to qualify a candidate for the physical ability test. This can be done before a conditional offer of employment without violating ADA guidelines. It will prevent a potential liability in a negligent hiring lawsuit or a workman's compensation claim (Czarnecki, 2014, pp. 46-48). Generally, when the physical ability test, aptitude test, and interview are completed successfully, the applicant is ranked based on points or alphabetically, and placed on an eligibility list until an offer of conditional employment is made after which additional examinations must be passed to remain on the eligibility list (Martin \& Gwynne, 2010).

Physical fitness is required in basic training but seldom is required or included in inservice training. Should agencies require continued physical fitness? In 2000, Martin wrote on police wellness as an inservice training requirement and found it to be almost non-existent (Martin, 2000). At that time, after the physical fitness requirements in basic training were met, less than five percent of police agencies mandated a continued physical fitness program. Police unions have a 
tendency to restrict physical fitness standards. City administrators tend to use the requirement as a throw-away concession during contract negotiations. The examinations used for placing applicants on an eligibility list can meet federal ADA requirements by not asking medical questions until making a conditional offer. There is still an unresolved U. S. Supreme Court case that has not yet addressed the question on whether a psychological examination is considered a medical examination under ADA. But on July 5, 2005, the Seventh Circuit Court of Appeals

invalidated an employer's use of the Minnesota Multiphasic Personality Inventory Test (MMPI), the country's most widely used personality test. See Karraker v. Rent-A-Center, Inc., 2005 U.S. App. LEXIS 11142 (June 14, 2005). The court ruled that the test constituted a medical examination within the meaning of the Americans With Disabilities Act, 42 U.S.C. § 12101 et seq. ("ADA"), and that the employer's use of the test violated the ADA (Giles, 2005, para. 1).

Many agencies give the psychological evaluation before the conditional offer of employment; but based on this legal opinion, it probably violates ADA requirements. After the conditional offer is made, agencies should continue with the least expensive examinations once the number of candidates is smaller.

\section{Discussion}

\subsection{Summary of Types of Training}

There are various types of police training. As stated previously, Gaines and others (2003, p. 374) state there are three types of police training: (1) basic, (2) inservice, and (3) specialized training, with Peak and Glensor (2012), identifying a fourth type of training: roll-call training used during shift changes for about 30 minutes prior to the start of the next shift. Generally, roll-call training involves sharing information of incidents that took place during the previous two shifts (p. 187). Actually, this type would fall under the inservice training category. For example, the Reno, Nevada, Police Department utilizes a police training officer (PTO) program which Peak and Glensor claim is more relevant to community police training (2012). The PTO program has taken the place of the field training officer (FTO) program in many agencies (2012, p. 184). Inservice training is best served using the Knowles Theory of Andragogy as advocated by Peak and Glensor for adult learners who are self-directed and want to be involved in the learning process. Trainers become facilitators rather than directors of learning (pedagogy) under this theory. This allows officers to see the significance of training relating to their jobs. The relevancy comes from their discussion of experiences on the job (2012, pp. 179-180). Basic training extends into field training. There are two types of basic training: (1) agency-sponsored and (2) preservice basic training.

\subsection{Agency-Sponsored Basic Training}

The traditional basic training experience required by various states has expanded in the past 50 years from 300 to 1,400 hours. Currently, the length of basic training lasts from 12 and 36 weeks. Large cities have longer periods of basic training. The curricular content of basic training emphasizes legal and behavioral issues as opposed to the technical skill aspects of policing (Walker \& Katz, 2008, p. 144). There are negative aspects of attending an agency sponsored academy including taxpayer costs and sometimes preconceived notions about policing from instructors' war stories. Many instructors (and academy content) do not emphasize policing as service and order maintenance activities more often than law enforcement (Gaines et al., 2003, p. 376).

Continued physical ability and wellness training are mostly neglected topics in the traditional academy and after probation. Few agencies require mandatory fitness even though research shows decreased stress when fitness standards are followed. The small percentage of agencies that require fitness are not the only ones dealing with physically fit criminals (Martin \& Gwynne, 2010). Criminals and juveniles are generally physically fit and are between the ages of 14 and 24. Police need to be in the best physical condition when they have to deal with them. Physical fitness reduces negative stress, promotes good health, reduces worker's compensation claims, and since research shows that police officers live about 10 years less than the general population, increases longevity (Martin \& Gwynne, 2010). Another type of basic training is preservice basic training.

\subsection{Preservice Basic Training}

Self-sponsored pre-employment training is when aspiring candidates pay their own training costs before employment. This type of training has gained popularity around the country (Martin, 2014; More \& Miller, 2007, p. 507). Community college preservice basic training programs have emerged during the past several years in an attempt to increase applicants and reduce agency costs. Community colleges combine their associate's degree with basic training by providing credit for completing training and count the basic training curriculum toward the number of required credits for the degree. Essentially, basic training then is an add on program (an internship for example), to complete degree requirements instead of an integration of learning outcomes of both the academic and training curriculum. 


\subsection{Integrated Preservice}

To accommodate an agency's two-year degree requirement, a few community colleges have integrated their associate degree course learning outcomes with the basic training learning outcomes which in the opinion of many, is a better experience. While examining the content of criminal justice required courses and electives and comparing the courses with the content of the training course, one can see that 90 percent of the content of the basic training courses are the same as the criminal justice academic courses (Martin, 2014). Some states also have self-sponsored preservice basic training academies leading to certification without the pursuit of community college associate degrees. Critical to the recruitment and selection processes are selection criteria that allow agencies to find recruits with the attributes that predict success in t3aining and policing. Basic training and subsequent field training based on this selection criteria should be validated and confirm that the right decision was made in selecting recruits who fit in with the culture of the agency.

\subsection{Field Training Validates Selection}

Field training during probation is a continuation of basic training. Field training validates the selection process (Gaines et al., 2003, p. 378). It indicates that the right persons were selected for the job. It gives agencies the chance to objectively evaluate new officers. According to Swank and Conser, personnel evaluation researchers, the evaluations should be based on an objective evaluation of performance and not subjective judgments (as cited in More \& Miller, 2007, p. 510). CALEA standard 33.4.3 "establishes a field training program for all newly sworn officers with a curriculum based on tasks of the most frequent assignments." Field training varies by agency and is mostly run by well-trained field training officers (FTOs). According to CALEA (2006). Probationary officers should be rotated with various assignments with a well-established evaluation process.

Field training should be standardized, and those candidates that illustrate a deficiency in achieving required outcomes can be directed into remedial training. Based on the standards, the FTO provides a critique of the officer's task performance. The FTO provides continued direction and training of the recruit throughout the probation period. Recruit performance is evaluated by the FTO, first by observing how the officer handles situations followed by shadowing the recruit in a separate vehicle until the FTO is satisfied the officer can work alone. When a deficiency results in a non-trainable defect, the recruit can be terminated. If it can be remediated, further training is warranted. By showing proof of the probationary recruit not meeting the specific learning outcomes as prescribed, personality conflicts ending in unwarranted dismissals of the probationary officers are eliminated. Field training programs are an extension of basic training and are extremely stressful because of the constant evaluation of the probationary officer (Oliver, 2020, p.139). It serves as a weeding out process for most agencies. Field training prepares officers to be on their own during patrol rather than riding with the FTO. Some officer deficiencies can be remediated and agencies may attempt to save the new recruit by further training, whereas, some agencies continue the screening out philosophy demonstrated during the selection process (Martin, 2014; 2016). Probationary periods vary between six months and two years, with most around 18 months. The longer periods have been adopted because agencies realize that the first year involves basic training (and time before) and field training, so to really evaluate a probationary officer, 12 months make more sense to fully evaluate an officer and possibly remediate deficiencies.

Supervisors should decide the criteria of field training process with documentation that officers are performing adequately. The results of field training can be used to update the processes of selection and training for the next group of recruits. Sharing information among selection personnel and FTOs about observed weaknesses, personality traits, and past conduct issues can be useful in updating and improving both selection and field training (Martin \& Gwynne, 2010). This interdisciplinary sharing and collaboration by the evaluators/trainers support successful selection and training. Inservice training serves as a fine-tuning process for officers.

\subsection{Inservice Training}

Allen (1978) wrote about management training of sergeants in Great Britain. He stressed training should include a cross-disciplinary approach to understanding problems encountered by police. This should include psychology, interpersonal communications, leadership, motivation, building morale, assessment, and appraisal. Allen reasoned that by including these areas in supervisor training, a better understanding of officers' responses, insights, and exchanges with witnesses and victims are entrenched. While inservice training can be more general, specialized training is more specifically geared toward enhancing professionalism and career skills. Both specialized and inservice involve career development (Oliver, 2020). The enhanced skills and knowledge foster officer self-confidence and competence, which in turn creates a professional bearing, or behavior, and more likely commands the respect of the public (Martin, 2014). The issues that need specific training may include low morale from a lack of confidence to perform tasks, use-of-force complaints, employee grievances, and complaints of verbal abuse during citizen contacts. Officers are frequently criticized when they do not handle even common situations very well. The community and administration criticism of a 
lack of ability, fails to realize that they hired the individual being criticized. They put the standards in place for selection. Bad publicity from poor service creates a negative perception of the officer and the department.

Some states have laws that allow untrained police to carry guns and work on the streets and special events as part-time reserves. Although large departments restrict these situations, smaller departments may not (Oliver, 2020). Many agencies provide minimal training based on the state's legal requirement; hence, training may lack sufficient standards and curriculum. Safety as well as reputation have to be considered when there is a lack of proper training. There may be injuries and loss of life when there is a lack of sufficient training (Thibault, Lynch, \& McBride, 2004, p. 349), but sometime this is also true because of a lack of police presence. Training programs need to be current and relevant. Qualied full-time instructors should be used rather using than managers or supervisors. Furthermore, when college professors are used, they should relate their teaching/training to street-level policing (p. 350). Civil suits are more frequent when officers are poorly trained. Supplemented by attribute targeted selection procedures, training and stress reduction programs can reduce agency liability. Courts have ruled that a good faith is not a sufficient defense for a failure to train lawsuit (p. 349).

\subsection{Civil Liability and Failure to Train}

Since the U.S. Supreme Court decision in City of Canton v. Harris in 1989, several civil lawsuits have been opened throughout the U.S. failure to train police officers is one frequent claim. Furthermore, training supervisors can also reduce liability. Researchers found that failure to supervise is just as bad as the failure to train and is found in many civil lawsuits as a secondary claim (Ross, 2000, p. 137). Additional research on police liability found that inservice training for dealing with citizens should be continuous to avoid civil lawsuits and to provide a sound defense to legal claims (Ross, 2000, p. 137). The courts use the standard of deliberate indifference when reviewing of failure-to-train lawsuits. Training as you may recall, is rudimentary to a profession (More \& Miller, 2007). Other professional rudiments include authority, specialization, self-governing discretion, a defined body of information, continuing education and training, self-regulating standards, a code of ethics, and an internalized aspect of societal service (More \& Miller, 2007, p. 505).

\section{Conclusion}

It should be explored whether well-trained officers are more confident and skilled and are better workers and tend to be more effective overall. Judgment and decision making of officers is affected by training, both positively and negatively. As stated previously by Gaines and co-researchers, there are three types of police training: (1) basic, (2) inservice, and (3) specialized training (2003, p. 374), and Peak and Glensor (2012) wrote about a fourth type of training: roll-call training used during shift changes for about 30 minutes prior to the start of the next shift. To be effective, training should be relevant and conducted by full-time instructors knowledgeable about policing practice and research. Topics should include contemporary issues and legal updates. Inservice training should be ongoing, especially issues on physical and mental health, physical fitness, and legal updates.

\section{References}

Allen, R. J. (1978). Effective supervision in the police service. England. London: McGraw-Hill. Retrieved from www.ncjrs.gov/App/ Publications/abstract.aspx?ID=59733

Benton, S. R., \& Martin, R. H. (2012). Police crisis intervention: The need to train. Law Enforcement Executive Forum, 13(1), 110-127.

Commission on Accreditation for Law Enforcement Agencies (CALEA). (2006). Standards for law enforcement agencies: The standards manual of the law enforcement agency accreditation program. Fairfax, VA: CALEA.

Cordner, G., \& Cordner, K. (2014). Human resource issues faced by small and large agencies. The Police Chief, 91(3), 14-15.

Czarnecki, F. (2014). The role of pre-employment screenings: Medical screening of police applicants. The Police Chief, 91(3), 46-51.

FBIjobs.gov. (n.d.). Special agents' physical requirements. Retrieved from https://fbijobs.gov/career-paths/special-agents/physical-requirements

Gaines, L. K., \& Worrall, J. L. (2012). Police administration (9 $9^{\text {th }}$ ed.). Clifton Park, NY: Delmar/Cengage

Gaines, L. K., Worrall, J. L., Southerland, M. D., \& Angell, J. E. (2003). Police administration (2nd ed.). Boston: McGraw-Hill.

Gies, T. P. (2005). Do you often have a hard time getting out of bed in the morning? Can a psychological test violate the ADA? Crowell.Com. Retrieved from 
https://www.crowell.com/NewsEvents/AlertsNewsletters/all/Do-You-Often-Have-A-Hard-Time-Getting-Out-Of-B ed-In-The-Morning-Can-A-Psychological-Test-Violate-The-ADA

Grossi, D. (2007). Mandatory fitness for inservice officers: The final word. Police One.com. Retrieved from https://www.policeone.com/police-products/fitness-health-wellness/articles/final-word-mandatory-fitness-standard s-for-in-service-officers-XhMHxtnm6n2fHWJk/

Hunter, F. (1994). A call for change. Command Publication: Illinois Association of Chiefs of Police, 4, 20-23.

International Association of Chiefs of Police (IACP). (2008). Improving 21 st century policing through priority research. The IACP's national law enforcement research agenda. Alexandria, VA: IACP.

Martin, R. H. (2000). Wellness: A matter of health. In W. Doerner \& M. L. Dantzker (Eds.), Police organization and management: Contemporary issues (pp. 279-307). Boston: Butterworth-Heinemann.

Martin, R. H. (2014). An alternative approach to preservice police basic training: Combining training and education learning outcomes. Community College Journal of Research and Practice, 38(11), 995-1007. https://doi.org/10.1080/10668926.2012.726939

Martin, R. H. (2016). Attributes in Florida for police recruit success in training and career. Law Enforcement Executive Forum Journal, 16(4), 55-75. https://doi.org/10.19151/LEEF.2016.1604e

Martin, R. H. (April., 2020). Psychological assessment in police selection: Common methods of personality evaluation. Accepted for publication in Law Enforcement Executive Forum.

Martin, R. H., \& Gwynne, J. L. (2010). An assessment of essential police candidate aptitudes and requirements in Alabama: Police training technologies. Law Enforcement Executive Forum, 11(1), 83-103.

Martin, R. H., \& Hamilton, S. (2014). Selecting the right recruit: Attributes preferred by Illinois and Iowa police chiefs. Law Enforcement Executive Forum, 14(2), 94-114.

Martin, R. H., Gwynne, J. L., \& Hamilton, S. (2013). A comparison of police chief essential police recruit attributes in Georgia, Alabama, and South Carolina. Law Enforcement Executive Forum, 13(3), 37-56.

Martin, R.H. (Sept. 17, 2019). Choosing police recruits for job longevity and successful careers in policing: Preferred attributes of police chiefs. EC Psychology and Psychiatry, 8(10), 1061-1078. Retrieve from www.ecronicon.com/ecpp/pdf/ECPP-08-00556.pdf

Miller, L. S., More, H. W., \& Braswell, M. C. (2017). Effective police supervision ( $8^{\text {th }}$ ed.). NY: Rutledge. https://doi.org/10.4324/9781315400822

Moore, D., Martin, R. H., \& Lin, C. (2019). Police chiefs' perspectives regarding obesity among law enforcement officers. Law Enforcement Executive Forum, 19(1), 6-20. Retrieve from

https://iletsbeiforumjournal.com/index.php/hikashop-menu-for-categories-listing/product/387-

More, H. W., \& Miller, L. S. (2007). Effective police supervision ( $5^{\text {th }}$ ed.). New York: Lexis-Nexis, Anderson

Oliver, W. M. (2020). Policing America: An introduction (2 ${ }^{\text {nd }}$ ed.). Fredrick, MD: Wolters Kluwer

Peak, K. J., \& Glensor, R. W. (2012). Community policing and problem solving: Strategies and practices (6th ed.). Upper Saddle River, NJ: Pearson.

Ross, D. L. (2000). Emerging trends in police failure to train liability. Policing: An Inter-national Journal of Police Strategies \& Management, 23(2), 169-193. https://doi.org/10.1108/13639510010333796

Thibault, E. A., Lynch, L. M., \& McBride, R. B. (2004). Proactive police management (6th ed.). Upper Saddle River, NJ: Pearson/Prentice Hall.

Walker, S., \& Katz, C. M. (2019). The police in America: An introduction (8th ed.). New York: McGraw-Hill.

Weber State University (n.d.). WSU police academy physical training requirements. Retrieved from http://continue.weber.edu/policeacademy/fitness.aspx

\section{Copyrights}

Copyright for this article is retained by the author(s), with first publication rights granted to the journal.

This is an open-access article distributed under the terms and conditions of the Creative Commons Attribution license which permits unrestricted use, distribution, and reproduction in any medium, provided the original work is properly cited. 